\title{
Entrevista com os editores do selo Companhia das Letrinhas
}

A entrevista aqui apresentada foi concedida via e-mail pelos dois editores entre os dias 17 e 23 de maio de 2017. O foco da entrevista são as traduções publicadas pelo selo Companhia das Letrinhas: mercado de tradução, escolhas da equipe de tradutores, revisões, intervenções por parte dos editores, etc.

Antônio Augusto Castro do Nascimento, 24 anos, natural de Guaratinguetá - SP, é formado em letras pela Universidade de São Paulo, faz parte da equipe editorial dos selos: Seguinte e Companhia das Letrinhas do Grupo Companhia das Letras.

Gabriela Ubrig Tonelli, 24 anos, natural de São Paulo - SP, formada em Editoração pela Escola de Comunicações e Artes da USP. Desde 2014, faz parte da equipe editorial dos selos: Seguinte e Companhia das Letrinhas do Grupo Companhia das Letras.

\section{Entrevista sobre o mercado de traduções}

Como vocês veem o mercado de tradução de obras para o público infantil e juvenil no Brasil hoje? Há muita demanda?

Editores (eds): No catálogo da Companhia das Letrinhas, cerca de metade das obras são internacionais, ou seja, precisam ser traduzidas. 0 catálogo da Seguinte (o selo juvenil do Grupo Companhia das Letras), porém, 
é quase inteiramente traduzido. Então existe uma demanda grande sim, mas especialmente maior na literatura juvenil. E essa questão é perceptível não só aqui, mas em outras editoras também!

\section{Como é a escolha do tradutor para cada obra?}

Costumamos pensar nos gostos pessoais do tradutor e no tipo de livro que ele costuma traduzir mais. Por exemplo, para um livro de poesia, é interessante escolhermos um tradutor que seja poeta ou que já tem bastante familiaridade com o assunto, se especializou nesse tipo de tradução etc. No caso da literatura infantil e/ou juvenil, por exemplo, precisamos de um tradutor que consiga se adaptar à linguagem desses públicos. Um tom de “tiozão” num livro pra adolescentes não rola, haha (sic).

Vocês contratam por trabalho ou já tem tradutores fixos na editora?

Editores (eds): Nossos tradutores são freelances, então contratamos por livro. É claro que, no caso de uma série, sempre fazemos de tudo para manter o mesmo tradutor, por exemplo. Nos livros infantis às vezes acontece de um ou outras traduções serem internas, realizadas por alguém da equipe editorial, mas essas são as exceções.

Os autores costumam influenciar nessa escolha do tradutor ou no próprio trabalho depois de pronto? Existe intervenção por parte de editoras do texto de origem?

Editores (eds): Quando contratamos os direitos de publicação de livro estrangeiro aqui no Brasil, às vezes existe uma cláusula no contrato de que a tradução precisa ser aprovada pelo agente literário (que representa o autor), pelo autor ou pela editora original. Nesse caso, se alguma adaptação não for aprovada por uma dessas instâncias, mudamos a edição e seguimos o pedido delas. No geral, os autores não costumam influenciar na escolha dos tradutores. A escolha é da equipe editorial, que sempre procura escolher o melhor tradutor para o livro e, em alguns casos, manter sempre o mesmo tradutor para as obras de um mesmo autor. 
Como relação às coleções, vocês preferem que um mesmo tradutor traduza toda a obra do autor?

Editores (eds): Sim, em caso de séries e coleções, procuramos manter sempre o mesmo tradutor (assim mantemos também o mesmo tom de texto ao longo dos (ivros).

Qual a influência de vocês como editores no texto traduzido? Vocês fazem modificações/recomendações?

Editores (eds): Após recebermos a tradução, ela é encaminhada para a preparação de texto, que pode ser feita por alguém da equipe interna (o que costuma acontecer com os livros infantis) ou por um preparador de texto externo (o que normalmente acontece com os livros juvenis e/ou "adultos"). Essa é a primeira edição do texto, que será padronizado e conferido (tanto em questões ortográficas e gramaticais quanto se a tradução está correta, se o arquivo está completo, se alguma adaptação poderia ser melhorada etc.). Após a preparação, o texto passa pela edição, ou seja, pela leitura e por alterações feitas pelo editor do livro. 0 texto traduzido normalmente sofre muitas mudanças, especialmente de adequação de tom ao público, além de outras escolhas editoriais, como escolha final do título, de nomes de personagens etc. Quando necessário (e quando são grandes mudanças), há uma conversa entre o editor e o tradutor para rever alguns pontos etc. Mas não necessariamente toda mudança no texto traduzido passa pelo tradutor (um erro, por exemplo, será corrigido e nem sempre mencionado ao tradutor).

Qual a preocupação de vocês com relação ao texto traduzido para o público infantil?

Editores (eds): A grande preocupação talvez seja deixar o texto realmente próximo do leitor. Ele deve conversar com seu público, ou seja, com a criança brasileira. Isso envolve tanto a questão do tom usado (além de 
sempre seguirmos o original, claro; por exemplo, textos mais formais na língua original devem manter-se mais formais em português) quanto a questão de adaptação de contexto e de palavras (por exemplo, um livro que fala sobre sorvetes deve trazer sabores conhecidos pelas crianças aqui no Brasil, por isso muitas vezes existe uma conversa entre editor-tradutor e editorautor/agente literário/editora original para que haja uma adaptação e a melhor opção seja a que chegue até o leitor).

Qual a posição de vocês com relação à domesticação $e$ estrangeirização do texto fonte?

Editores (eds): Já exemplificamos algumas vezes em que achamos importante uma "adaptação" para um contexto mais brasileiro, mas a proposta não é mudar a "cara" do livro ou simplesmente abrasileirá-lo - o importante é o leitor entender a mensagem e se sentir próximo da história, personagens etc.; mesmo que ela se passe em um lugar diferente. 